\title{
EFEKTIVITAS DUTA GENRE DALAM MEMASYARAKATKAN PROGRAM GENRE BKKBN DI KOTA PADANG
}

\author{
Yatsuko Juliana Sukamto \\ Jurusan Ilmu Administrasi Publik, Fakultas Ilmu Sosial, Universitas Negeri Padang \\ Email: yatsu_ko@yahoo.com

\section{Hasbullah Malau} \\ Jurusan Ilmu Administrasi Publik, Fakultas Ilmu Sosial, Universitas Negeri Padang \\ Email: hasbullahmalau@fis.unp.ac.id
}

\begin{abstract}
This article aims to determine the effectiveness, constraints faced by Duta Genre in socialize Genre Program BKKBN in Padang City. As well as knowing how far the role of government overcome the genre ambassador problem in socialize genre BKKBN program. This research uses a qualitative approach which is interpreted as a research resulting in a descriptive form of words that can be observed and directed to the background individually and in society. A qualitative research approach is a complex, indepth approach. The informant is derived from the management of the generation planning Program, including Kasubid area of population control, counseling and mobilization DP3AP2KB Kota Padang, and from the Genre ambassadors. Based on the results of the study, the genre ambassadors in socialize BKKBN program in Padang City can be said to be effective. Padang City people feel the benefits of the presence of the genre ambassadors in socialize Genre BKKBN program. The changes that occurred after the ambassador genre can also be seen from the problem of young marriage, Napza, free sex, and readiness of human resources who are ready to receive the BKKBN program through the genre ambassadors by proving the public can Overcome obstacles. But there is still a shortage in the implementation of the genre ambassador activities in socialize Genre BKKBN program is weak supervision done to the event of the ambassador of the genre itself.
\end{abstract}

Keywords: Effectiveness, ambassador genre, socialize, and genre program

How to Cite: Yatsuko Juliana Sukanto dan Hasbullah Malau. 2019. Efektivitas Duta Genre dalam Memasyarakatkan Program Gendre BKKBN di Kota Padang. 3(2): pp. 91-102. DOI: https://doi.org/10.24036/jess/vol3-iss2

\section{Pendahuluan}

Undang-Undang Nomor 52 Tahun 2009pasal 48 ayat 1 (b) tentang perkembangan kependudukan dan pembangunan keluarga, dimana kualitas remaja harus meningkat dengan cara pemberian akses informasi, pendidikan, konseling, dan pelayanan tentang kehidupan berkeluarga. Pengembangan PIK sangat diperlukan 
bagi remaja sebagaiwadah pelayanan informasi dan konseling dan sebagai motivator. Selanjutnya ikon Duta Genre memberikan manfaat lebih ketika mensosialisasikan dan mempromosi program Genre.

Dalam bkkbn.go.id menjelaskan untuk melakukan pemilihan duta Genre di atur dalam bentuk petunjuk teknis yang berisi mekanisme pelaksanaan pemilihan duta Genre, tujuan, sasaran dan hasil yang diharapkan pemilihan duta genre tersebut. Pemilihan duta genre yang dilakukan tiap tahunnya berasal dari kalangan pendidikan dan kalangan masyarakat. Sekarang ini partisipasi dan dukungan para pemangku kepentingan dan mitra dalam memsukseskan program Program GenRe terus meningkat. Setelah terpilihnya duta Genre, maka segala kegiatan Duta genre ini akan diawasi dan dibina oleh forum Genre Indonesia, yang mana tugas dari forum Genre Indonesia ini tertuang dalam SK kepala BKKBN no. 141. Tahun 2017. Dinas Pemberdayaan Perempuan Perlindungan Anak Penduduk dan Keluarga Berencana (DP3AP2KB) terus berupaya meningkatkan keberhasilan Program GenRe dengan csara pemilihan duta Genre setiap tahunnya. Hal ini dilakukan karena kemerosotan moral para remaja dari berbagai kalangan sangat tinggi. Program GenRe merupakan sangat bermanfaat karena selalu mengutamankan karakter generasi menjadi lebih kuat, serta untuk menghindari pernikahan dibawah umur, seks pranikah, narkoba dan lainnya.

Menurut Sri Ambarwati sebagai koordinator advokasi hak kesehatan seksual dan reproduksi LP2M dalam sumbar.com mengungkapkan bahwa terjadi peningkatan tren pernikahan dibawah umur di sumatera Barat. Sementara menurut BPS pada tahun 2016 terdapat 10,22 persen pasangan menikah di usia anak. Sementara Kepala Badan Narkotika Nasional Provinsi (BNNP) Sumatera Barat Brigjen Pol Khasril Arifin mengungkapkan bahwa sebanyak 66.612 orang di Sumbar tercatat terlibat dalam penyalahgunaan narkoba baik kategori coba pakai, teratur pakai maupun pecandu. Dia juga mengumgkapkan bahwa pelajar masih sangat rentan terjangkit narkotika. Selanjutnya Badan Narkotika Nasional (BNN) melakukan survey terhadap terhadap pengguna narkotka. Hasilnya adalah 24 persen pengguna narkotika adalah pelajar (merdeka.com, diakses tanggal 5 Februari 2019).

Pada penelitian ini peneliti fokus melihat efektivitas duta genre dalam memasyarakatkan program BKKBN yang tertuang dalam UU No.52 Tahun 2009 pasal $48 \mathrm{~b}$ tentang perkembangan kependudukan dan pembangunan keluarga. Namun, pada kenyataannya meski berbagai kegiatan yang merupakan perwujudan dari program genre telah diimplementasikan Badan Pemberdayaan Perempuan dan Keluarga Berencana Kota Padang, diantaranya melalui duta genre terus melakukan sosialisasi kepada pelajar dan mahasiswa dalam bentuk seminar, kompetisi-kompetisi, dan pembentukan kelompok-kelompok remaja yang di bina mengenai pengetahuan perencanaan berkeluarga yang ideal tidak menunjukan hasil yang maksimal.

Beberapa studi yang berhubungan dengan program BKKBN adalah penelitian yang dilakukan oleh Eva Alfajriani mengenai program promosi genre bagi kaum remaja yang terkait di Kecamatan Barong Tongkok Kabupaten Kutai Barat sudah cukup baik. Akan tetapi masih banyak hal yang harus dapat dioptimalkan lagi agar program promosi genre untuk generasi muda di Kecamatan 
Barong Tongkok Kabupaten Kutai Barat dapat diakses dan dipahami paragenerasi muda Kutai Barat. Penelitian yang dilakukan oleh Yulianti (2017) yang menyatakan bahwa program-program BKKBN harus dilaksanakan dengan berbagai strategi yaitu pendekatan, ramah remaja, pembelajaran, pelembangaan dan pencapaian. Strategi komunikasi yang dilakukan dalam memasyarakatkan program BKKBN yaitu dengan menggunakan cara tatap muka Melida (2015). Lebih lanjut Susanti (2015) mengungkapkan bahwa media sangat berperan dalam melakukan sosialisasi program BKKBN. Lebih lanjut Utami (2015) menyatakan bahwa penyuluhan BKKBN tentang genre sangat efektif dilakukan di sekolahsekolah.

Dalam upaya penyelesaian persoalan penduduk dan implikasinya, pemerintah pusat dan kabupaten hendaklah menciptakan suatu kebijakan atau program yang sifatnya lebih khusus atas persoalan kependudukan yang dimaksud. Terkait hal tersebut, Badan Kependudukan dan Keluarga Berencana Nasional (BKKBN) bersama-sama Operasi Perangkat Daerah, menjalankan fungsi lembaganya dan berwacana tentang revolusi pembangunan kependudukan dan keluarga berencana yang tertuang dalam Undang-undang No. 52 Tahun 2009 tentang Perkembangan Kependudukan dan Pembangunan Keluarga yang kemudian dikuatkan dengan terbitnya Peraturan Presiden No. 26 Tahun 2010 tentang $\mathrm{BKKBN}$, dimana peraturan tersebut mengikat lebih teknis mengenai tugas dan fungsi BKKBN. Menurut Nofrijal sekretaris utama BKKBN upaya-upaya kongkrit yang dilahirkan oleh BKKBN sendiri tertuang dalam Rencana Strategis BKKBN diataranya adalah menurunkan rata-rata laju pertumbuhan penduduk tingkat nasional; meningkatkan median Usia Kawin pertama perempuan (tahun). Namun, pada implementasi BKKBN bersama-sama Operasi Perangkat Daerah (OPD) mengalami berbagai kendala. Untuk itu BKKBN segera mengambil langkah-langkah akselerasi dan kegiatan-kegiatan strategis yang harus diikuti oleh BKKBD tiap provinsi.

Melihat kondisi sekarang ini jumlah penduduk usia produktif yang merupakan remaja dan banyaknya pengaruh-pengaruh negatif yang akan menjerumuskan remaja mencoba seks pranikah, menjadi pecandu narkoba dan pernikahan di usia anak maka pemerintah harus lebih meningkatkan sosialisa terhadap bahaya laten yang rentan terhadap remaja tersebut. Apalagi Kota Padang punya potensi besar dalam menghadapi bonus demografi 2035 justru dikhawatirkan akan menjadi boomerang bilamana dalam proses capaian jangka pendek saja tidak tertangani dengan baik.

Fokus penelitian ini adalah permasalahan yang yang akan dikaji terhadap efektivitas duta genre dalam memasyarakatkan program BKKBN. Agar permasalahan dalam penelitian ini tidak menyimpang dari tujuan penelitian, maka pembahasan dalam penelitian ini adalah; (1) efektivitas yaitu untuk mengukur tepat kebijakan, tepat pelaksanaan, tepat target, tepat lingkungan, tepat proses. (2) kendala yang dihadapi duta genre dalam memasyarakatkan program BKKBN yaitu dari segi partisipasi masyarakat, masalah teknis dan SDM, serta dari segi dana. (3) peran pemerintah dalam mengatasi permasalahan duta genre dalam memasyarakatkan program BKKBN yaitu sebagai komunikator, membina relationship, dan membentuk image dari organisasi. 
Berdasarkan latar belakang yang telah dijabarkan pada halaman sebelumnya, peneliti tertarik melakukan penelitian ini dengan judul" Efektivitas Duta Genre dalam Memasyarakatkan Program Genre BKKBN di Kota Padang."

\section{Tinjauan Kepustakaan}

\section{Konsep Efektivitas}

Emerson dalam Handayaningrat (1994) menjelaskan tentang efektivitas adalah pengukuran yang dimaksud dalam artian tujuan dari rancangan yang telah ditentukan sebelumnya. Efektivitas berhubungan dengan hasil yang dicapai dan memberikan kontribusi terhadap masyarakat banyak. Menurut Pratama Wira (2015) mengungkapkan bahwa efektivitas merupakan deskripsi dari tingkat keberhasilan atau keunggulan dalam mencapai sasaran yang telah ditentukan dan terkait dengan nilai-nilai yang bervariasi.Selanjutnya pendapat Sedarmayanti (1995) yang menyatakan bahwa efektivitas terbukti mewakili suatu ukuran yang memberikan gambaran sejauh mana sasaran dapat dicapai.

Efektifnya sebuah organisasi adalah apabila laporan yang dibuat tentang dirinya dan aktivitas-aktivitasnya dibuat sesuai dengan standar operational procedure (SOP) dan diterima berdasarkan fakta yang logis. Hal ini menyakini bahwa efektivitas merupakan bagian dari negosiasi yang berkelanjutan. Dalam menetapkan efektivitas organisasi proses yang dipakai adalah mencakup pengamatan terhadap lingkungan yang tiada henti guna menjamin bahwa hasil dari program yang dilaksanakan oleh organisasi dapat diterima.

Berdsarkan pendapat di atas dianyatakan bahwa konsep efektivitas bersifat multi dimensional, dengan kata lain efektivitas berbeda dengan dasar ilmu yang dimiliki walaupun akhir dari efektivitas adalah keberhasilan tujuan yang dicapai.Sebuah organisasi dikatan efektif apabila memenuhi kriteria-kriteriayang dikemukan oleh Gibson (2006), adapun kriteria-kriteria tersebut: (1) Hasil produksi, merupakan ukuran keluaran utama organisasi dalam hal menambah penjualan, mempertimbangkan pasar, dokumen yang diperlukan, rekanan yang muncul, dan sebagainya, (2) Efesiensi merupakan penggunaan sumber daya yang langka oleh organisasi. Efisiensi di antara rasio antara biaya dengan biaya atau waktu yang digunakan (3) Kepuasan atas keberhasilan organisasi dalam pemenuhan kebutuhan karyawan atau anggotanya. (4) Penyesuaian, Partisipan, Efektivitas, Partisipasi, Penggantian Karyawan, Absensi, Kelambanan, Kelambanan, Kelimpahan, Kelayakan, dan Kelayakan Perubahan-perubahan eksternal seperti persaingan, kebutuhan pelanggan, kualitas produk, dan sebagainya (5) kelangsungan merupakan tanggung jawab organisasi dalam peningkatan kapasitas dan potensi untuk berkembang. Dalam praktik, para manajer menggunakan indikator jangka pendek untuk keberlangsungan jangka panjang.

Pendapat Gibson dapay disimpulkan bahwa sebuah organisasi dikatakan efektif dalam menjalankan program pemeritahan apa bila input dan output seimbangsetelah diukur berdasarkan rasio antara keuntungan dengan biaya atau waktu yang digunakan. Organisasi harus selalu merespons terhadap perubahan 
eksternal dan internal atau selalu dapat menyesuaikan dengan keadaan, karena hal tersebut dapat membantu meningkatkan kelangsungan hidup organisasi.

Cara mengukur tingkat efektivitas sebuah program yang dilakukan dengan cara melakukan penilaian ketepatan dari program tersebut. Setiawan (1998) mengatakan bahwa perbandingan antara tujuan yang akan dicapai dengan keluaran program merupakan cara mengukur efektivitas sebuah program yang dijalankan. Menurut Budiani (2007) dalam mengukur efektivitas ada beberapa variabel yang bisa dijadikan patokan demi keberhasilan sebuah progran sebagai berikut (1)Ketepatan sasaran program, (2) Sosialisasi program (3)Tujuan program (4) Pemantauan. Selanjutnya menurut Nugroho (2011:650) indikator yang digunakan untuk mengukur efektivitas adalah (1) Tepat Kebijakan, (2) Tepat Pelaksana, (3) Tepat Target, (4) Tepat Lingkungan, (5) Tepat Proses. Indikator dari pendapat Nugroho (2011) selanjutmya dijadikan sebagai indikator efektivitas yang dogunakan dalam penelitian ini.

\section{Konsep Program Generasi Berencana (Genre)}

Usaha peningkatan pengetahuan serta pembinaan remaja pemerintah mengeluarkan kebijakan yaitu Undang-undang Nomor 52 tahun 2009 pasal 48b yaitu peningkatan kualitas remaja dengan pemberian akses informasi, pendidikan, konseling, dan pelayanan tentang kehidupan berkeluarga. Program Generasi Berencana adalah suatu program untuk memfasilitasi terwujudnya Tegar Remaja, yaitu remaja yang berperilaku sehat, terhindar dari risiko Triad Kesehatan Reproduksi Remaja, yakni tiga resiko yang dihadapi oleh remaja, yaitu menikah diusia anak, seks pranikah dan narkoba. Untuk memwujudkan keluarga kecil bahagia dan sejahtera dapat diwujudkan dengan perencanaan kehidupan berkeluarga. Salah satu syarat dari Generasi Berencana adalah remaja yang punya pengetahuan luas tentang permasalahan remaja, bersikap dan berperilaku sebagai orang terdidik. Genreharus bisa menyelesaikan pendidikan secara terencana, mempunyai perencanaan karir, mempunyai perencanaan menikah berdasarkan siklus Kesehatan Reproduksi.

Berdasarkan hal tersebut duta genre berharap mampu mengatasi persoalan yang ada pada remaja, tidak melalkukan pernikahan dini, seks pramenikah, dan narkotika.

\section{Kebijakan dan Strategi Program Generasi Berencana}

Adapun strategi Program Generasi Berencana yang dirancang oleh pemerintah adalah sebagai berikut: (1) Melakukan orientasi, workshop dan pelatihan, serta magang. (2) Membentuk dan melakukan pengembangan PIK remaja dan BKR. (3) Materi program Generasi Berencana dikembangkan sesuai pekembangan tekhnologi. (4) Bersama-sama stakeholder, dan mitra kerja terkait meningkatkan kemitraan (5) secara nberjenjang dilakukan peningkatkan pembinaan, monitoring dan evaluasi secara berjenjang. (www.bkkbn.go.id, diakses tanggal 5 Februari 2019). 


\section{Metodologi Penelitian}

Penelitian ini menggunakan pendekatan kualitatif, yang berusaha mengungkapakan dan memahami realitas yang ada di lapangan sesuai dengan kondisi real di lapangan. Yang menjadi fokus dalam penelitian ini adalah permasalahan yang yang akan dikaji terhadap efektivitas duta genre dalam memasyarakatkan program Genre BKKBN. Informan pada penelitian ini berasal dari pengelola Program Generasi Berencana meliputi Kasubid Bidang Pengendalian Penduduk, Penyuluhan dan Penggerakan DP3AP2KB Kota Padang, dan anggota dari program Genre.

Sumber data dari penelitian ini adalah dari responden yang di wawancara. Peneliti memilih responden yang benar-benar terkait dan orang-orang yang mengetahui permasalahan yang akan diteliti.Metode pengumpulan data yang akan digunakan dalam penelitian ini adalah observasi lapangan, Wawancara dan Dokumentasi.Untuk menguji keabsahan data peneliti menggunakan teknik triangulasi sumber yaitu (1)Membandingkan data hasil pengamatan dengan hasil wawancara. (2) Membandingkan apa yang dikatakan di depan umum dengan apa yang dikatakan orang secara pribadi.

\section{Hasil Penelitian dan Pembahasan}

Program GenRe ini telah diperkenalkan kepada masyarakat seluruh penjuru Indonesia. Dalam hal pelaksanaan pemilihan duta Genre BKKBN bekerjasama dengan SKPD-KB di masing-masing daerah. SKPD merupakan motor utama pelaksana program. Melalui DP3AP2KB Kota Padang duta genre berupaya memberikan pemahaman dan informasi kepada generasi muda dan keluarga remaja mengenai perencanaan kehidupan berkeluarga di Kota Kota Padang. Menurut Nugroho (2003) keefektifan suatu kebijakan dilihat dari lima tepat yang perlu dipenuhi. Pertama, apakah kebijakan itu sendiri sudah tepat, kedua adalah tepat pelaksanaannya, ketiga adalah tepat target, keempat adalah tepatlingkungan dan kelima adalah tepat proses.

\section{A. Efektivitas Duta Genre dalam Memasyarakatkan Program BKKBN di Kota Padang}

\section{Ketepatan Kebijakan Pemerintah}

Berdasarkan pendapat narasumber, pihak pemerintah pusat sebagai pembuat dan pemegang kebijakan merasakan bahwa kebijakan mengenai duta genre dapat memecahkan permasalahan yang ada. Keberhasilan suatu kebijakan dalam memecahkan masalah berkaitan pula dengan pertimbanganpertimbangan apa saja yang ada pada saat perumusan kebijakan itu berlangsung. Mengenai lembaga pembuat kebijakan apakah sejalan dengan kewenangan yang lembaga itu miliki, karena apabila suatu kebijakan tidak sesuai dengan kewenangan dari lembaga tersebut bagaimana kebijakan itu dapat berjalan dengan baik untuk memecahkan permasalahan yang ada.Dapat dikatakan bahwa dengan adanya program genre dapat membantu pemerintah 
dalam mengurangi menikah di usia anak, seks sebelum menikah dan narkoba serta permasalahan yang dihadapi para remaja di Kota Padang dapat di kurangi. Keterlibatan duta genre dan masyarakat dalam semua tahapan kegiatan, mulai dari pengorganisasian, penyusunan rencana program, merupakan salah satu wujud dalam menentukan suksenya program genre di masyarakat.

Nugroho (2011) menyatakan bahwa ketepatan kebijakan dapat dilihat dari sejauhmana kebijakan yang ada telah berisi cara mengatasi permasalahan. Apakah kebijakan tersebut telah dirumuskan berdasarkan karakter masalah, dan apakah kebijakan dibuat oleh pemerintah telah sesuai dengan karakter kebijakannya.

Hasil penelitian ini tentang ketepatan kebijakan sejalan dengan landasan hukum tentang duta Genre yaitu Undang-Undang Nomor 52 Tahun 2009 pasal 48b yaitu dalam upaya meningkatan kualitas generasi mudadapat dilakukan dengan cara pemberian akses informasi, pendidikan, konseling, dan pelayanan tentang kehidupan berkeluarga. Jadi dapat disimpulkan bahwa kebijakan pemerintah dalam mengatasi permasalahan remaja sudah tepat. Namun pelaksana pembuat kebijakan ini juga perlu mengetahui apakahsesuai dengan kewenangan yang lembaga miliki dan mengevaluasi setiap kebijakan yang dibuat. Sehingga dalam menetapkan kebijakan program BKKBN tentang duta genre dalam memasyarakatkan program tetap berada pada jalurnya yaitu penanganan masalah Pernikahan Usia Anak, Seks Pra Nikah dan NAPZA. Sehingga kebijakan ini dinilai tepat dibuat oleh lembaga yang memiliki wewenang dan dijalankan pula oleh lembaga yang memiliki domainnya terhadap program pemerintah tersebut. Sedangkan untuk pelaksanaan pemilihan duta Genre diatur dalam petunjuk teknis (Juknis) yang dibuat oleh BKKBN dan kegiatan duta genre akan dibina dan diawasi melalui Forum Genre Indonesia yang ditungkan dalam SK Kepala BKKBN No.141 Tahun 2017.

\section{Ketepatan Pelaksanaan}

Berdasarkan hasil wawancara dengan beberapa informan dapat di simpulkan bahwa selain adanya satuan kerja yang di bentuk pada tingkat pusat, provinsi dan kabupaten, tim pelaksana juga ada pada tiap jenjang pemerintah. Setelah itu adanya juga duta genre dalam memasyarakatkan program BKKBN. Dari semua elemen-elemen yang terkait dalam pelaksanaan program BKKBN ini masyarakat ini juga berperan sangat besar untuk keberhasilan program tersebut. Karena program ini adalah program memasyarakatkan program pemerintahan maka peranan masyarakat atau orang tua ditunutut besar dalam pelaksanaannya. Pada penelitian ini pelaksanaan program BKKBN tentang duta genre melibatkan berbagai unsur dan instansi terkait. Diharapkan peran pemerintah daerah selaku pembina dapat mendukung secara optimal penyelenggaraan program BKKBN tentang program. Sehingga perlu untuk mengetahui siapa saja aktor yang terlibat dalam implementasi program BKKBN tentang duta genre. Pelaksanaan pemilihan Duta Genre diatur dalam bentuk Petunjuk Teknis Pemilihan Duta Genre yang dibuat oleh BKKBN. 
Semua tingkat pemerintah saling mempengaruhi, apabila tingkat pusat kurang bisa berkoordinasi secara baik dengan tingkat provinsi, lalu provinsi dengan kabupaten, kabupaten dengan kecamatan, kecamatan dengan pemerintah desa dan seterusnya. Maka bisa saja terjadi kekacauan pada tahap pelaksanaan, karena masing-masing tingkatan pemerintah mempunyai tugas masingmasing dan bersifat berjenjang. Menurut Nugroho (2011) mengungkapkan bahwa tepat pelaksanaannya apabila semua aktor implementasi kebijakan tidaklah hanya pemerintah.

Hasil penelitian ini sejalan dengan petunjuk teknis yang dibuat oleh BKKBN yang mengatur tentang mekanisme pelaksanaan, tujuan, sasaran, dan hasil yang diinginkan. Jadi dapat disimpulkan bahwa pelaksanaan pemilihan duta Genre dan kegiatan duta genre sudah tepat. Dengan adanya keterlibatan berbagai pihak seperti yang dijelaskan oleh narasumber di atas, memang sebenarnya permasalahan remaja yang terjadi di Indonesia bukan hanya tanggung jawab pemerintah. Peranan seluruh lapisam masyarakat juga dinilai perlu berperan aktif dalam upaya pengentasan permasalahan remaja terutama di Kota Padang.

\section{Ketepatan Sasaran}

Berdasarkan hasil wawancara dengan beberapa informan terkait ketepatan sasaran dari pelaksanaan duta Genre ini dapat disimpulkan bahwa semua pihak mendukung program genre dalam upaya meningkatkan kemampuan masyarakat untuk memprioritaskan, merancang, melaksanakan, mengelola dan memantau program- program BKKBN. Ketepatan sasaran ini sangat penting untuk dilihat, karena apabila sasaran tidak tercapai maka nantinya dapat dikatakan suatu program tersebut kurang berhasil dilaksanakan di suatu desa. Tujuan duta genre itu sendiri adalah bisa mensosialisasikan program genre tidak hanya kepada anggota PIK saja, namun kelingkungan sekitar yang lebih luas, minimal orang 'tau' adanya program genre. Target berikutnya bisa mengaktifkan PIK PIK remaja dan mahasiswa yang ada. Jangan sampai PIK nya ada namun kegiatannya tidak ada (tidak aktif). Hal ini bisa dikatakan bahwa masyarakat menjadi mengerti, peduli dan secara aktif mensukseskan pelaksanaan program. Sasaran dalam pemilihan duta Genre diatur dalam bentuk petunjuk teknis pemilihan duta Genre yangdibuat oleh BKKBN yang berisi mekanisme pelaksanaan, tujuan, sasaran, dan hasil yang diinginkan setelah terpilihnya duta Genre.Koordinasi yang dilakukan oleh pusat dengan provinsi, lalu provinsi dengan kabupaten, dan kabupatren dengan kecamatan dan desa maka intervensi di tingkat pemerintahan jarang sekali terjadi.Adanya intervensi dari kebijakan pemerintah lainnya mempengaruhi dalam pelaksanaan program pemerintah yang dimasyarakatkan oleh duta genre dari mulai tingkat pusat, provinsi, kabupaten.

Menurut Nugroho (2011:650) Ketepatan sasaran berkenaan dengan target yang diintervensi sesuai dengan yang direncanakan, apakah tidak ada tumpang tindih dengan intervensi lain, apakah targetnya dalam kondisi siap untuk diintervensi kebijakan lain, ataukah tidak, dan apakah intervensi 
implementasi kebijakan bersifat baru atau memperbarui implementasi kebijakan sebelumnya.

Hasil penelitian tersebut sejalan dengan petunjuk teknis yang dibuat oleh BKKBN tentang pelaksanaan pemilihan Duta Genre. Jadi dapat disimpulkan bahwa sasaran dalam pelaksanaan Duta Genre dalam memasyarakatkan progrem BKKBN telah tepat. Hal ini dibuktikan dengan antusiasme masyarakat dalam melaksanakan program pemerintah dengan menjadi duta genre untuk melaksanakan program genre. Karena kebijakan mengenai pemilihan duta genre ini sudah tepat, melihat tujuan dari program genre ini sendiri adalah bagaimana menyiapkan remaja yang berkualitas dan produktif dan mampu menghadapi kondisi saat ini (pergaulan bebas, obat terlarang, tauran, nikah muda). Disamping itu sasaran dari program genre ini utamanya adalah remaja, maka kami menilai bahwa remaja jugalah yang lebih efektif dalam melakukan pedekatan ke remaja lainnya.

\section{Ketepatan Lingkungan}

Berdasarkan hasil wawancara dengan beberapa informan yang menyatakan bahwa koordinasi yang dilakukan secara berjenjang ini merupakan interaksi yang memiliki alur. Dengan adanya koordinasi yang seperti itu, maka sosialisasi yang dilakukan dalam pelaksanaan program BKKBN juga dilakukan secara berjenjang oleh duta genre. Interaksi dan koordinasi yang baik antar lembaga terkait akan meminimalisir hal-hal menyimpang atau yang tidak sesuai dengan pedoman pelaksanaan program BKKBN. Maka itu perlunya semua tingkatan pemerintah dalam pelaksanaan program BKKBN melakukan koordinasi dengan baik agar tidak terjadi tumpang tindih dan saling membantu dalam pelaksanaan program BKKBN khususnya di tingkat Kabupaten/Kota.

Menurut Nugroho (2011:650) Tepat lingkungan yaitu lingkungan kebijakan dan pelaksana kebijakan dengan lembaga lain yang terkait.

\section{Ketepatan Proses}

Berdasarkan hasil wawancara dengan beberapa informan dapat disimpulkan bahwa proses pelaksananya itu ditingkat pusat, provinsi sama kabupaten membentuk namanya satuan kerja ya. Satuan kerja ini SK nya dari BKKBN itu untuk menyalurkan dananya. Disamping satuankerja juga ada namanya tim pelaksana itu di semua tingkatan juga, tingkat pusat, provinsi, kabupaten. Selain adanya satuan kerja yang di bentuk pada tingkat pusat, provinsi dan kabupaten, tim pelaksana juga ada pada tiap jenjang pemerintah. Setelah itu adanya juga duta genre dalam memasyarakatkan program BKKBN. Dari semua elemen-elemen yang terkait dalam pelaksanaan program BKKBN ini masyarakat ini juga berperan sangat besar untuk keberhasilan program tersebut. Karena program ini adalah program memasyarakatkan program pemerintahan maka peranan masyarakat atau orang tua ditunutut besar dalam pelaksanaannya. Semua tingkat pemerintah saling mempengaruhi, apabila tingkat pusat kurang bisa berkoordinasi secara baik dengan tingkat provinsi, lalu provinsi dengan kabupaten, kabupaten dengan kecamatan, kecamatan 
dengan pemerintah desa dan seterusnya. Maka bisa saja terjadi kekacauan pada tahap pelaksanaan, karena masing-masing tingkatan pemerintah mempunyai tugas asing-masing dan bersifat berjenjang.Dengan adanya keterlibatan berbagai pihak seperti yang dijelaskan oleh narasumber di atas, memang sebenarnya permasalahan remaja yang terjadi di Indonesia bukan hanya tanggung jawab pemerintah. Peranan seluruh lapisam masyarakat juga dinilai perlu berperan aktif dalam upaya pengentasanpermasalahan remaja terutama di Kota Padang.

\section{B. Kendala Duta GenRe dalam Memasyarakatkan Program BKKBN}

Walaupun mendapat tanggapan positif dalam pelaksanaan bukan tidak ada kendala dalam memasyarakatkan program BKKBN. Dengan adanya pengaruh antara tanggapan publik yang positif akan sebuah program maka dalam melaksanakan program tersebut masyarakat akan merasa lebih bertanggung jawab dan akan lebih siap dalam menangani atau mengatasi hambatan-hambatan yang ada pada saat pelaksanaan program BKKBN melalui duta genre.

Berdasarkan narasumber hambatan yang sering terjadi ketika duta genre dalam memasyarakatkan program BKKBN yaitu belum maksimal dalam mencapai target, karena belum semua sekolah dan daerah yang dikunjungi untuk diberikan sosialisasi. Kendalanya hingga saat ini belum ada anggaran untuk duta genre melakukan sosialisasi termasuk tranport pun tidak ada, kebanyak duta genre siswa siswa yang masih bersekolah sehingga waktu untuk sosialisasi terbatas.

Selanjutnya kendala yang dihadapi selama menjadi duta genre yaitu ada beberapa kendala dari masyarakatnya sendiri, karna duta genre ini turun melakukan sosialisasi dan promosi dari berbgai macam kalangan masyarakat, tentunta jika tidak memiliki teknik komunikasi yang baik bagaimana cara agar masyarakat menegrti dan paham pakan hal yang disampaikan itu akan sulit. Masyarakat bukannya menolak akan program ini, namun belum semuanya paham akan manfaat dan cara melaksanakan program genre ini. Dan juga kendala lainnya yang dirasakan adalah tidak adanya anggaran minimal transportasi saja untuk duta genre, sehingga tidak semua sekolah dan daerah dikota padang dapat dikunjungi, hal ini berbeda dengan beberapa kabupaten kota lainnya di sumatera barat yang mana duta genrenya diberikan anggaran khusu dalam menajalnkan tugasnya.

\section{Upaya Pemerintah dalam Mengatasi Permasalahan Duta Genre dalam Memasyarakatkan Program BKKBN}

Dalam mensukseskan program pemerintah yang disosialisasikan oleh duta genre, terdapat beberapa kendala yang dihadapi oleh duta genre selama berada di lapangan. Peran pemerintah untuk menyelesaikan permasalahan yang dihadapi duta genre sangat dibutuhkan agar pelaksanaan program BKKBN dapat berjalan dengan efektif. 
Menurut narasumber upaya pemerintah (BKKBN Provinsi) dalam mengatasi kendala yang dihadapi duta genre kota padang yaitu pihak BKKBN Provinsi tidak bisa membantu secara langsung dalam memberikan dukungan dana/anggara kepada pihak kab/kota yang ada. Namun setiap tahunnya kami menganugrahkan AYAH dan BUNDA GenRe Sumatera Barat yang mana ini dipilih tiap kab/kota ada ayah bunda genrenya. Ayah bunda genre yang dipilih merupakan stakeholder yang berpengaruh di daerah tersebut, seperti walikota bupati, tim penggerak pkk kab/kota, dsb. Hal ini dilakukan agar mereka mampu mesupport dan memudahkan perihal urusan duta genre dalam berkegiatan di kab/kota tsb. Ini salah satunya terlihat sangat nyata saat diadakan malam grandfinal pemilihan duta genre, pasti walikota/bupati datang mengahdiri dan menyalempangi langsung para pemenang.

Sedangkan hal yang dilakukan DP3AP2KB Kota Padang dalam menangani kendala yang dihadapi duta genre ini adalah dengan membuat anggaran untuk duta genre tahun 2020, dan juga untuk permasalahan lapangan yang dihadapi duta genre pihak kantor melaksanakan Bimbingan teknis (bimtek) Kesehatan Reproduksi Remaja tiap tahunnya.

\section{Kesimpulan}

Berdasarkan hasil penelitian di lapangan, secara umum dapat dikatakan bahwa:

1. Efektivitas duta Genre dalam mensuksekan dan mensosialisasikan program genre BKKBN di Kota Padang sudah tepat seperti Kebijaksanaan, Pelaksanaan, sasaran/ Target . Tepat Lingkungan, dan prosesnya sudah tepat.

2. Kendala yang dihadapi duta genre dalam memasyarakatkan program BKKBN sehingga belum maksimal dalam mencapai target, karena belum semua sekolah dan daerah yang dikunjungi untuk diberikan sosialisasi. Kendalanya hingga saat ini belum ada anggaran untuk duta genre melakukan sosialisasi termasuk transport pun tidak ada, kebanyakan duta genre siswa siswa yang masih bersekolah sehingga waktu untuk sosialisasi terbatas.

3. Pihak BKKBN Provinsi tidak bisa membantu secara langsung dalam memberikan dukungan dana/anggara kepada pihak kab/kota yang ada. Namun setiap tahunnya kami menganugrahkan AYAH dan BUNDA GenRe Sumatera Barat yang mana ini dipilih tiap kab/kota ada ayah bunda genrenya. Ayah bunda genre yang dipilih merupakan stakeholder yang berpengaruh di daerah tersebut, seperti walikota bupati, tim penggerak pkk kab/kota, dsb. Hal ini dilakukan agar mereka mampu mesupport dan memudahkan perihal urusan duta genre dalam berkegiatan di kab/kota tsb. Ini salah satunya terlihat sangat nyata saat diadakan malam grandfinal pemilihan duta genre, pasti walikota/bupati datang mengahdiri dan menyalempangi langsung para pemenang. 


\section{Referensi}

Aziza, Tri Noor dan Itcianday. 2017. Peranan "Incar" (Informasi Cerdas Ala Remaja) Dalam Program Genre (Generasi Berencana) Di Kabupaten Nunukan. JKKP : Jurnal Kesejahteraan Keluarga dan Pendidikan. http://doi.org/10.21009/JKKP.

Damayanti, Saleh, Lumintang 2012. Efektivitas Variety Show Program Keluarga Berencana Melalui Media Televisi. Jurnal Komunikasi Pembangunan. Vol.10, No.2

Handayaningrat, Suwarno. 1982. Administrasi Pemerintahan Dalam Pembangunan Nasional. Jakarta: PT. Gunung Agung

Riant Nugroho. 2011. Public Policy: Dinamika Kebijakan - Analisis Kebijakan Manejemen Kebijakan. Jakarta : Elex Media Komputindo

Sabaru, H, Liando Daud, dan Neni 2018. , Kinerja Badan Koordinasi Keluarga Berencana Nasional Kota Manado Dalamelaksanaan Program Keluarga Berencana.Jurnal Jurusan Ilmu Pemerintahan Volome 1 No. 1 Tahun 2018

Susanti, Herdiana Ayu. 2015. Strategi Komunikasi Badan Kependudukan Dan Keluarga Berencana Nasional (BKKBN). Jurnal Komunikasi ASPIKOM, Volume 2 Nomor 4, hlm 243-254

Tika Pabundu, 2005, Budaya Organisasi dan Peningkatan Kinerja Perusahaan, Jakarta, Bumi Aksara

Utami, Devi Dwi Yana.2015. Penyuluhan Program BKKBN Mengenai Generasi Berencana (GenRe) dan Sikap Remaja. Jurnal Simbolika/Volume 1/Nomor 2

Yulianti D. 2017. Program Generasi Berencana (Genre) Dalam Rangka Pembangunan Manusia Menuju Pembangunan Nasional Berkualitas. jurnal analisis sosial politik. volume 1 , no 2 . 